\title{
Islet neogenesis: an apparent key component of long-term pancreas adaptation to increased insulin demand
}

\author{
H Del Zotto ${ }^{1}$, M I Borelli ${ }^{1}$, L Flores ${ }^{1}$, M E García ${ }^{1}$, C L Gómez \\ Dumm $^{1}$, A Chicco ${ }^{2}$, Y B Lombardo ${ }^{2}$ and J J Gagliardino ${ }^{1}$ \\ ${ }^{1}$ CENEXA - Centre of Experimental and Applied Endocrinology (UNLP-CONICET, PAHO/WHO Collaborating Centre), University of La Plata School of \\ Medicine, La Plata, Argentina \\ ${ }^{2}$ Department of Biochemistry, University of Litoral, Santa Fe, Argentina \\ (Requests for offprints should be addressed to H Del Zotto, CENEXA (UNLP-CONICET), Facultad de Ciencias Médicas, UNLP, 60 y 1201900 La Plata, \\ Argentina; Email cenexa@speedy.com.ar)
}

\begin{abstract}
This study aimed to determine the relative importance of different functional and morphological pancreatic changes induced by the chronic administration of a sucrose-rich diet (SRD) to maintain normal glucose homeostasis. Male Wistar rats were fed either sucrose (SRD) or starch (CD) for 6 and 12 months. At both periods, serum glucose and triacylglycerol levels were significantly higher $(P<0 \cdot 05$; paired and unpaired Student's $t$-test) in SRD rats. Serum insulin levels were significantly lower in SRD only at 12 months. At 6 months, the insulin secretion doseresponse curve in SRD rats showed a shift to the left that was no longer observed at 12 months, when SRD islets decreased their response to $16 \mathrm{mM}$ glucose. At 6 months, SRD rats showed a significant increase in $\beta$-cell volume density (Vvi) and islet cell replication rate, together with a
\end{abstract}

decrease in $\beta$-cell apoptotic rate. Changes were not detected in the percentage of PDX-1- and islet neogenesis associated protein (INGAP)-positive cells. Conversely, at 12 months, there was a significant decrease in $\beta$-cell Vvi and in the percentage of PDX-1-positive cells; the islet cell replication rate was not modified, and the number of apoptotic $\beta$-cells increased significantly. No signs of increased neogenesis or INGAP-positive cells were recorded at any period in SRD rats. Our results show that SRD rats are unable to develop functional and morphological pancreatic reactive changes sufficient to maintain normal glucose and triacylglycerol levels for a long period. Such failure could be ascribed to their inability to increase the rate of neogenesis and of INGAP production.

Journal of Endocrinology (2004) 183, 321-330

\section{Introduction}

The chronic administration of a sucrose-rich diet (SRD) to normal rats induces an insulin-resistant state characterized by moderate fasting hyperglycemia, increased triglyceride and free fatty acid (FFA) levels, normoinsulinemia and a modest increase in body weight (Cohen et al. 1977, Lombardo et al. 1996, Chicco et al. 2003). Islets isolated from these rats have a normal insulin content (Lombardo et al. 1996, Del Zotto et al. 2002), but their secretion pattern is characterized by the absence of the first peak and the enhancement of the second phase of insulin release in response to glucose (Chicco et al. 2003, Pighin et al. 2003). Islets from rats fed SRD for 9 months also had an increased content of triglyceride and reduced pyruvate dehydrogenase complex activity (PDHc) (Pighin et al. 2003). All these characteristics resemble those found in people with type 2 diabetes (Polonsky et al. 1996, Clark et al. 2001, Weir et al. 2001, Deng et al. 2004). After 6 months of SRD administration, the pancreas of these rats showed a significant increase in both number of islets and $\beta$-cell area (Lombardo et al. 1996, Del Zotto et al. 2002).

The effect of SRD on glucose homeostasis and on pancreatic function and morphology has also been studied in hamsters (Del Zotto et al. 1999, 2000, Massa et al. 2001). In hamsters fed this diet for 12 months, serum glucose and triacylglycerol levels remained within normal range. Insulin secretion was enhanced in vivo and in vitro, and $\beta$-cell mass increased due to an increment in replication rate and islet neogenesis, while there were no changes in the rate of $\beta$-cell apoptosis. It is not clear as yet why rats and hamsters present such an uneven response to the increased insulin demand induced by sustained SRD administration.

In adult mammals, the mass of pancreatic $\beta$-cells undergoes dynamic changes to maintain serum glucose levels within normal range (Montanya et al. 2000), even under extremely different conditions such as pregnancy and obesity (Parsons et al. 1992, Milburn et al. 1995). The resultant $\beta$-cell mass depends on a subtle balance between cell growth and differentiation, and cell death 
(Shafrir et al. 1999, Bonner-Weir 2000). These processes are controlled by several transcription and humoral factors (Bonner-Weir \& Smith 1994, Edlund 1998, Gradwohl et al. 2000, Jensen et al. 2000, Perfetti et al. 2000, McKinnon \& Docherty 2001), probably including islet neogenesis-associated protein (INGAP) (Rosenberg et al. 1983, Flores et. al 2003, Gagliardino et al. 2003). Disruption of this balance may lead to an impairment of glucose homeostasis, such as the glucose intolerance developed with ageing, with a reduction in $\beta$-cell replication rate (Bonner-Weir 2000, Montanya et al. 2000). So far, it has not been established whether all the processes involved in this balance have either a similar or different importance in gaining a functional $\beta$-cell mass sufficient to maintain glucose homeostasis within the normal range.

In an attempt to answer this question, which is critical to understand the pathogenesis of type 2 diabetes and to develop appropriate strategies for the prevention and treatment of the disease, we have currently studied insulin secretion, volume density (Vvi), several indicators of islet neogenesis, and replication and apoptotic rate of $\beta$-cells, as well as the percentage of PDX-1- and INGAP-positive cells in normal Wistar rats fed SRD for 6 (SRD6) and 12 (SRD12) months. These results were then compared with those obtained previously in normal hamsters submitted to a similar dietary manipulation.

Our results show that SRD6 rats presented increased insulin secretion in vitro and $\beta$-cell Vvi, and this was ascribable to both an increase in $\beta$-cell replication rate and a decrease in apoptosis. However, all these functional and morphological changes were not observed in SRD12. The absence of increase in neogenesis rate and INGAP response might explain the limited capacity of the rat pancreas to cope with a sustained increased demand of insulin. The increased levels of glucose and triacylglycerol observed in SRD rats could also play a role in the mechanism (glucolipotoxicity) limiting the long-term reactive pancreas response.

\section{Materials and Methods}

\section{Animals and diets}

Normal male Wistar rats obtained from the National Institute of Pharmacology, Buenos Aires, Argentina (180$200 \mathrm{~g}$ body weight) were used. They were maintained in a temperature-controlled room at $23{ }^{\circ} \mathrm{C}$, with a fixed $12-\mathrm{h}$ light:12-h darkness cycle, and initially fed standard rat laboratory chow (Ralston Purina, St Louis, MO, USA) to standardise the nutritional status. After 1 week, the rats were randomly divided into two groups: the experimental group received a semisynthetic SRD $(63 \% \mathrm{w} / \mathrm{w})$, while the control rats $(\mathrm{CD})$ received the same semisynthetic diet but with starch instead of sucrose in the same proportion $(63 \% \mathrm{w} / \mathrm{w})$. Details of this procedure have been previously reported (Chicco et al. 1994). Both diets provided approximately $15.28 \mathrm{~kJ} / \mathrm{g}$ chow. The animals had free access to food and water and were maintained on their respective diets for 6 and 12 months.

The weight of each animal was recorded twice per week, while the individual caloric intake and weight gain of at least 10 animals in each group were assessed twice per week during the experimental period. On the day of the experiment, food was removed at $0900 \mathrm{~h}$, and experiments were performed between 0900 and $1200 \mathrm{~h}$. The experimental protocol was approved by the Human and Animal Research Committee of the School of Biochemistry, Universidad Nacional del Litoral, Santa Fe, Argentina.

\section{Blood parameters}

Rats were anaesthetised with an intraperitoneal injection of pentobarbital $(60 \mathrm{mg} / \mathrm{kg}$ body weight), and blood samples were drawn from the jugular vein and centrifuged at $4{ }^{\circ} \mathrm{C}$. The serum samples obtained were assayed either immediately or within the next 3 days after having been stored at $-20{ }^{\circ} \mathrm{C}$. Serum glucose (Bergmeyer 1974) and triacylglycerol (Laurell 1966) levels were determined by spectrophotometric methods. Insulin levels were determined by radioimmunoassay (RIA) (Herbert et al. 1965), using an antibody against rat insulin, a rat-insulin standard (Linco Research, St Charles, MI, USA) and highly purified porcine insulin labelled with ${ }^{125}$ I (Linde et al. 1980).

\section{Insulin secretion in vitro}

Groups of five islets isolated from pancreases of each experimental group by collagenase digestion (Lacy \& Kostianovsky 1967) were incubated for $60 \mathrm{~min}$ at $37^{\circ} \mathrm{C}$ in $0.6 \mathrm{ml}$ of Krebs-Ringer bicarbonate (KRB) buffer, $\mathrm{pH} 7 \cdot 4$, previously gassed with a mixture of $\mathrm{CO}_{2} / \mathrm{O}_{2}$ $(5 \% / 95 \%)$ and containing $0 \cdot 1 \%(\mathrm{w} / \mathrm{v})$ bovine serum albumin and different glucose concentrations $(0,2,4,6,8$ and $16 \mathrm{mmol} / \mathrm{l})$. At the end of the incubation period, insulin was measured in the medium by RIA (Herbert et al. 1965).

Immunohistochemical studies After removal of the whole pancreas, the fat tissue was carefully dissected away. Samples of the tail of the pancreas were then fixed in Bouin's fluid and embedded in paraffin wax; serial sections $(5 \mu \mathrm{m})$ were obtained from different levels of the blocks. Haematoxylin-eosin staining was used to assess the general structure of the pancreas. Each section from a given series was mounted on separate slides to stain adjacent sections for immunocytochemical identification of insulin-secreting cells ( $\beta$-cells) and glucagon-, somatostatin- and pancreatic polypeptide-secreting cells (non- $\beta$ cells). For this purpose, specimens were incubated with appropriate dilutions of our own guinea pig antiinsulin serum (1:20000) and a mixture of the other 
three rabbit antisera: antiglucagon (1:400), antipancreatic polypeptide (1:10 000) (both kindly provided by Novo Nordisk, Copenhagen, Denmark), and antisomatostatin (1:6000) (a gift from Dr S. Efendic, Department of Endocrinology, Karolinska Institute, Copenhagen, Denmark). The reaction was completed by the streptavidin-biotin complex method, with either peroxidase or alkaline phosphatase, together with carbazole and fast blue respectively as chromogens. Controls for serological specificity were made by preincubating a given antiserum with an excess of the corresponding hormone for $24 \mathrm{~h}$ at $4{ }^{\circ} \mathrm{C}$.

\section{Islet cell replication rate: double-immunolabelling studies}

Islet cell replication rate was estimated by detecting proliferating cell nuclear antigen (PCNA; 1:4000, Sigma) by a modified avidin-biotin peroxidase method (Hsu et al. 1981). We quantified and expressed the replication rate as the percentage of PCNA-labelled cells among the total islet cells.

We performed double staining of the following pairs: a) $\beta$ cells (insulin antibody) and PCNA (PCNA antibody), and $b$ ) non- $\beta$ cells (glucagon, somatostatin and pancreatic polypeptide pool) and PCNA. We then used the streptavidin-biotin complex method, with peroxidase and alkaline phosphatase, together with carbazole and fast blue respectively as chromogens. Incubations with primary antibodies were overnight, whereas those with the secondary biotinylated antibodies were for $30 \mathrm{~min}$.

\section{Indicators of islet neogenesis}

Cytokeratin immunostaining To reveal the presence of cytokeratin (CK)-positive cells, we used a specific monoclonal antibody for CK 19 (anti-CK clone 4.62; 1:40) (Sigma) and a panspecific cocktail of antibodies against human CK clone AE1-AE3 (DAKO), and the streptavidin-biotin complex method, with peroxidase and carbazole as chromogens. Before performing the staining, we treated deparaffinised sections with $250 \mathrm{ml}$ antigenretrieval solution (Vector Laboratories, Burlingame, CA, USA) for $10 \mathrm{~min}$ in a $500 \mathrm{~W}$ microwave oven (Madsen et al. 1997). The number of CK-positive cells was expressed as the percentage of the total islet cells counted. We also estimated the relationship between the islets and duct cells, measuring the percentage of the total number of islets in close contact with the ducts (Bertelli et al. 2001).

Detection of PDX-1- and INGAP-positive cells Sequential double staining for PDX-1 and INGAP detection in pancreatic cells was as follows. We first stained PDX-1 cells with the PDX-1 antibody (1:1200; kindly provided by Dr C. Wright, Department of Cell Biology, Vanderbilt University, Nashville, TN, USA), and revealed them as described above, using carbazole as chromogen; the same section was then immunostained with the INGAP antibody (1:250), except that alkaline phosphatase and fast blue (Sigma) were used as chromogens. Then, the percentage of cells expressing separately or co-expressing these two factors was quantified within each subsector of the pancreas, that is, islet, extrainsular, and duct cells (no fewer than 1000 each). Furthermore, glucagon (fluorescein) and somatostatin (Texas red) were used to reveal co-expression of these hormones with PDX-1 and INGAP.

$\boldsymbol{\beta}$-cell apoptotic rate: double-labelling studies To identify apoptotic cells, we used the propidium iodide technique (Scaglia et al.1997). Deparaffinised and hydrated sections were washed in PBS before incubation for $30 \mathrm{~min}$ in a dark, humidified chamber with a solution of propidium iodide ( $4 \mu \mathrm{g} / \mathrm{ml}$; Sigma) and ribonuclease A (100 $\mu \mathrm{g} /$ $\mathrm{ml}$; Sigma). Then, the sections pretreated with nonimmune sera from rabbit diluted in Tris-buffered saline ( $\mathrm{pH} 7 \cdot 4$ ) were incubated for $1 \mathrm{~h}$ with the glucagon antibody. After washing with PBS, fluorescence labelling of primary antibody was accomplished through a second incubation at room temperature for $45 \mathrm{~min}$ in the dark with the IgG-specific, fluorescein-conjugated, affinitypurified goat antibody (against heavy and light IgG chains; Jackson Immuno Research Laboratories, Baltimore, MD, USA). After another washing with PBS, the sections were mounted in Tris-glycerol $(\mathrm{pH} 8.4)$ for analysis by fluorescence microscopy. Using this double labelling, we obtained $\beta$-cells surrounded by an immunofluorescent ring of $\alpha$ cells. A Zeiss Axiolab epifluorescence microscope equipped with an HBO50 mercury lamp, together with two different filters, was used to visualise autofluorescent labelling. For the quantitative evaluation of immunofluorescence, positively labelled apoptotic endocrine cells were counted under a $\times 40$ objective lens in sections obtained from different levels of the blocks. The number of apoptotic cells was expressed as the percentage of the total number of islet cells counted.

Morphometrical analysis The morphometrical analysis was performed by videomicroscopy with a Jenamed 2 Carl Zeiss light microscope and an RGB CCD Sony camera in combination with OPTIMAS software (Bioscan, Edmons, WA, USA). We were then able to obtain the area occupied by the endocrine pancreas, the exocrine pancreas, the total pancreas, $\beta$ and non- $\beta$ cells, and several ratios and relationships, as described in the Results section. We also estimated the number of islets per unit area $\left(\mathrm{mm}^{2}\right)$ and $\beta$-cell Vvi. In addition, the ratio of islet cell area to number of islet cells $(\beta$ and non- $\beta$ ) was calculated to obtain cell size. Every islet or small group of endocrine cells was recorded in each section, thus obtaining the number and areas of both $\beta$ and non- $\beta$ cells. 
Table 1 Clinical and serological changes induced by SRD feeding

\begin{tabular}{|c|c|c|c|c|}
\hline & $\begin{array}{l}\text { Body weight } \\
\text { (g) }\end{array}$ & $\begin{array}{l}\text { Glycaemia } \\
(\mathrm{mmol} / \mathrm{l})\end{array}$ & $\begin{array}{l}\text { Triacylglycerol } \\
(\mathrm{mmol} / \mathrm{l})\end{array}$ & $\begin{array}{l}\text { Insulin } \\
(\mu \bigcup / \mathrm{ml})\end{array}$ \\
\hline \multicolumn{5}{|l|}{ Group } \\
\hline CD6 & $470 \cdot 0 \pm 13 \cdot 0$ & $6 \cdot 62 \pm 0 \cdot 17$ & $0 \cdot 47 \pm 0 \cdot 04$ & $55 \cdot 0 \pm 4 \cdot 9$ \\
\hline SRD6 & $556 \cdot 0 \pm 8 \cdot 0 \bullet$ & $8 \cdot 11 \pm 0 \cdot 14$ & $1 \cdot 57 \pm 0 \cdot 18$ & $50 \cdot 8 \pm 5 \cdot 8$ \\
\hline CD12 & $491 \cdot 0 \pm 9 \cdot 0$ & $6 \cdot 50 \pm 0 \cdot 20$ & $0.50 \pm 0.02$ & $58 \cdot 8 \pm 0 \cdot 2$ \\
\hline SRD12 & $520 \cdot 0 \pm 11 \cdot 0$ & $8 \cdot 30 \pm 0 \cdot 20$ & $2 \cdot 10 \pm 0 \cdot 02$ & $23 \cdot 0 \pm 2 \cdot 0$ \\
\hline
\end{tabular}

\section{Statistical analysis}

Data are presented as means \pm S.E.M. The statistical analysis was performed with paired and unpaired Student's $t$-test. A $P$ value of $<0 \cdot 05$ was considered significant.

\section{Results}

At the time of death, body weight in SRD6 was significantly higher than in the corresponding CD group $(P<0 \cdot 05)$, whereas such difference was not significant in SRD12 (Table 1).

Both serum glucose and triacylglycerol levels were also significantly higher in both SRD6 and SRD12 $(P<0 \cdot 05)$, triacylgycerol levels being even higher in SRD12 (Table 1). Serum insulin levels were comparable in SRD6 and CD6, whereas they were significantly lower in SRD12 than in either SRD6 or CD12 rats $(P<0 \cdot 05$; Table 1).

Insulin secretion elicited in vitro by different glucose concentrations is shown in Fig. 1. The dose-response curve obtained with islets from SRD6 shows a shift to the left (Fig. 1a), thus suggesting a decreased $\beta$-cell glucose threshold for the glucose stimulus. Such an effect was no longer observed in islets isolated from SRD12 animals (Fig. 1b), excepting glucose at $8 \mathrm{mM}$; these islets also released less insulin in response to $16 \mathrm{mM}$ glucose.

Sections from CD6 and SRD6 stained with haematoxylin-eosin revealed the general, normal histological pancreatic appearance. Furthermore, in both groups of animals, immunohistochemistry showed the usual topographic distribution of cells within the islets, with $\beta$-cells occupying the central zone and non- $\beta$ cells located at the islet periphery. Conversely, pancreases from SRD12 rats showed striking changes in morphology, with islets disrupted by fibrous tissue.

SRD6 animals showed a significant increment in the number of pancreatic islets per unit area and in $\beta$-cell Vvi $(P<0 \cdot 02)$, together with a $6 \cdot 8$-fold increase in $\beta$-cell replication rate (Table 2 and Fig. $2 \mathrm{a}$ and b); although to a lesser extent, non- $\beta$-cell Vvi was also larger in SRD than in CD animals $(0 \cdot 19 \pm 0.03$ vs $0.09 \pm 0.01 ; P<0 \cdot 02)$.
Comparable values, however, were recorded in endocrine cell size (in $\mu \mathrm{m}^{2}, \mathrm{CD}$ vs SRD): $\beta$-cells, $121 \cdot 48 \pm 9.73$ vs $118 \cdot 35 \pm 6 \cdot 46$; non- $\beta$ cells, $97 \cdot 55 \pm 6 \cdot 24$ vs $95 \cdot 59 \pm 7 \cdot 05)$.

The number of apoptotic cells in the endocrine pancreas of SRD6 animals (Fig. 2k; Table 2) was three times lower than that counted in CD rats (Fig. 2j) $(P<0 \cdot 02)$.

As an index of islet neogenesis, we measured the islet diameter, the percentage of CK-positive cells (Fig. 2g and $\mathrm{h}$; Table 3), the number of islets in close contact with the ducts, the number of insulin-reacting ductal
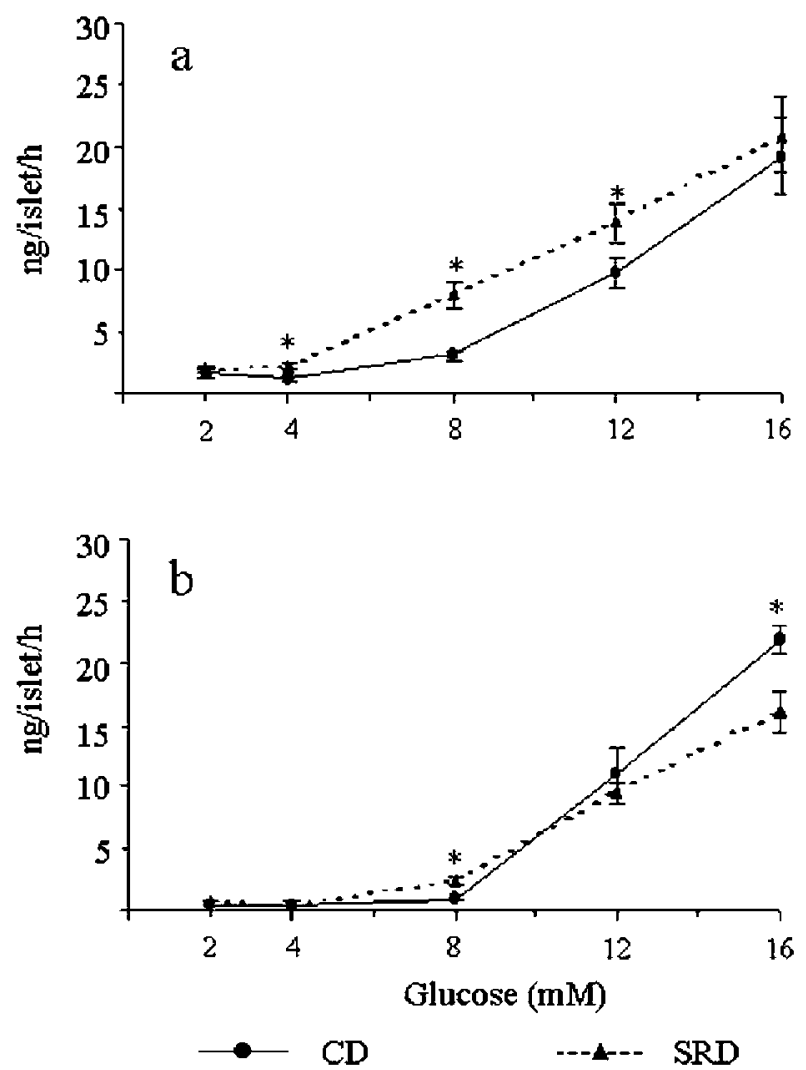

Figure 1 Insulin secretion: (a) CD6 vs SDR6 rats; (b) CD12 vs SDR12 rats. Each point in the line represents the mean of 15 cases from three different experiments \pm S.E.M. ${ }^{*} P<0 \cdot 05$. 
Table 2 Morphometrical analysis of pancreases from 6- and 12-month SRD or CD rats

\begin{tabular}{|c|c|c|c|c|}
\hline & $\begin{array}{l}\text { Number of islets } \\
\left(\mathrm{mm}^{2}\right)\end{array}$ & $\begin{array}{l}\boldsymbol{\beta} \text {-cell Vvi } \\
(\%)\end{array}$ & $\begin{array}{l}\text { PCNA index rate } \\
(\%)\end{array}$ & $\begin{array}{l}\text { Apoptotic index rate } \\
(\%)\end{array}$ \\
\hline \multicolumn{5}{|l|}{ Group } \\
\hline CD6 & $2 \cdot 0 \pm 0 \cdot 2$ & $0 \cdot 4 \pm 0 \cdot 2$ & $0.04 \pm 0.03$ & $4 \cdot 3 \pm 1 \cdot 1 \bullet$ \\
\hline SRD6 & $3 \cdot 3 \pm 0 \cdot 1$ & $1 \cdot 0 \pm 0 \cdot 1$ & $0 \cdot 30 \pm 0 \cdot 10$ & $1 \cdot 4 \pm 0 \cdot 5$ \\
\hline CD12 & $3 \cdot 0 \pm 0 \cdot 1$ & $0 \cdot 8 \pm 0 \cdot 1$ & $0 \cdot 10 \pm 0 \cdot 08$ & $4.9 \pm 0.5$ \\
\hline SRD12 & $1 \cdot 8 \pm 0 \cdot 1$ & $0.5 \pm 0.07$ & $0 \cdot 40 \pm 0 \cdot 20$ & $13 \cdot 5 \pm 0 \cdot 5$ \\
\hline
\end{tabular}

epithelium cells, and the percentage of islet PDX-1positive cells (Fig. 2d and e; Table 3). None of these indicators showed significant changes in pancreases from SRD6 rats. The percentage of INGAP-positive cells in the islets was comparable in both groups of animals at this period (Fig. 2d and e; Table 3). We did not record either $\beta$-cells or PDX-1- and INGAP-positive cells at duct level at either 6 or 12 months. PDX-1-positive cells were also undetectable among acinar cells.

Data recorded in SRD12 animals were markedly different: there was a significant decrease in the number of islets $(P<0.02)$ and in $\beta$-cell Vvi $(P<0.02)$, attaining values close to those recorded in CD6 rats (Table 2). We also observed a non-significant increase in PCNA index rate (Fig. 2c and Table 2).

Comparable values were recorded in both groups of animals in non- $\beta$-cell Vvi (\%) - CD vs SRD: $0 \cdot 10 \pm 0 \cdot 01$ vs $0 \cdot 20 \pm 0 \cdot 03 ; P<0 \cdot 02$. Similarly, islet cell-size values were also comparable in CD and SRD rats: $\beta$-cells, $129 \cdot 48 \pm 10 \cdot 00$ vs $121 \cdot 35 \pm 7 \cdot 00$; non- $\beta$ cells, $98 \cdot 00 \pm 6 \cdot 20$ vs $96 \cdot 00 \pm 7 \cdot 10 \mu \mathrm{m}^{2}$.

In contrast to what we found at 6 months, a significant increase in $\beta$-cell apoptotic rate was obtained in SRD12 rats $(P<0 \cdot 02)$. This increase was more marked when values were compared with those recorded in SRD6 rats (Fig. 21 and Table 2).

In SRD12, at 6 months, the islet neogenesis indicators did not show significant changes, except for a marked reduction in the percentage of islet PDX-1-positive cells recorded in SRD rats $(P<0 \cdot 005)$ (Fig. 2 f and Table 3 ).

The number of INGAP-positive cells decreased significantly in SRD12 $(P<0 \cdot 02)$ (Fig. $2 \mathrm{f}$ and Table 3$)$. This decrease was striking, considering that the number of INGAP-positive cells was significantly higher in CD12 than CD6. PDX-1- and INGAP-positive cells were not present at acinar and ductal level (data not shown).

\section{Discussion}

Our current results show that the chronic administration of SRD to normal rats induces uneven sequential changes both in insulin secretion and in the morphology of the endocrine pancreas.

It has been previously shown that the increased demand of insulin induced by different experimental procedures triggers a shift to the left in the in vitro dose-response curve profile of glucose-induced insulin release, in both rats and hamsters (Leahy 1996, Massa et al. 1997, 2001, Del Zotto et al. 1999). This effect could be partly ascribed to a change in the hexokinase:glucokinase ratio of islet cells (Leahy 1996, Massa et al. 2001), resulting in increased islet glucose metabolism (Massa et al. 2001). These results agree with the significantly higher second phase of insulin released by perifused islets in response to glucose reported in this animal model, as reported by Pighin et al. (2003). As described in that report, while insulin secretion in vitro was higher in SRD6 rats than in CD rats, their serum insulin levels were not. This apparent discrepancy between in vitro and in vivo results could be ascribed to the inhibitory effect of high levels of circulating fatty acids reported by our group (Pighin et al. 2003) and other authors as well (Zhou \& Grill 1995, Chen \& Reaven 1999). Consequently, the circulating levels of insulin in SRD6 rats were insufficient to cope with the increased peripheral demand of insulin, since these animals had significantly higher serum glucose and triacylglycerol levels than CD rats. These reactive changes in insulin secretion were no longer evident and even reversed at 12 months.

The fact that blood glucose levels are comparable in SRD6 and SRD12, and that insulin levels are lower in the former, would suggest that peripheral tissues have modified the sensitivity of SRD12 to insulin.

Our results indicate that normal rat islets can sustain the secretory overload elicited by the dietary-induced insulinresistant state only for a limited period of time. Such limitation could be genetically determined, since normal hamsters submitted to a similar chronic SRD treatment can sustain this response for a significantly longer period (Del Zotto et al. 1999, 2000). On account of the enhancing effect of endogenous insulin upon insulin and glucokinase transcription (Leibiger et al. 2002), glucose metabolism in the islets and insulin secretion of normal 

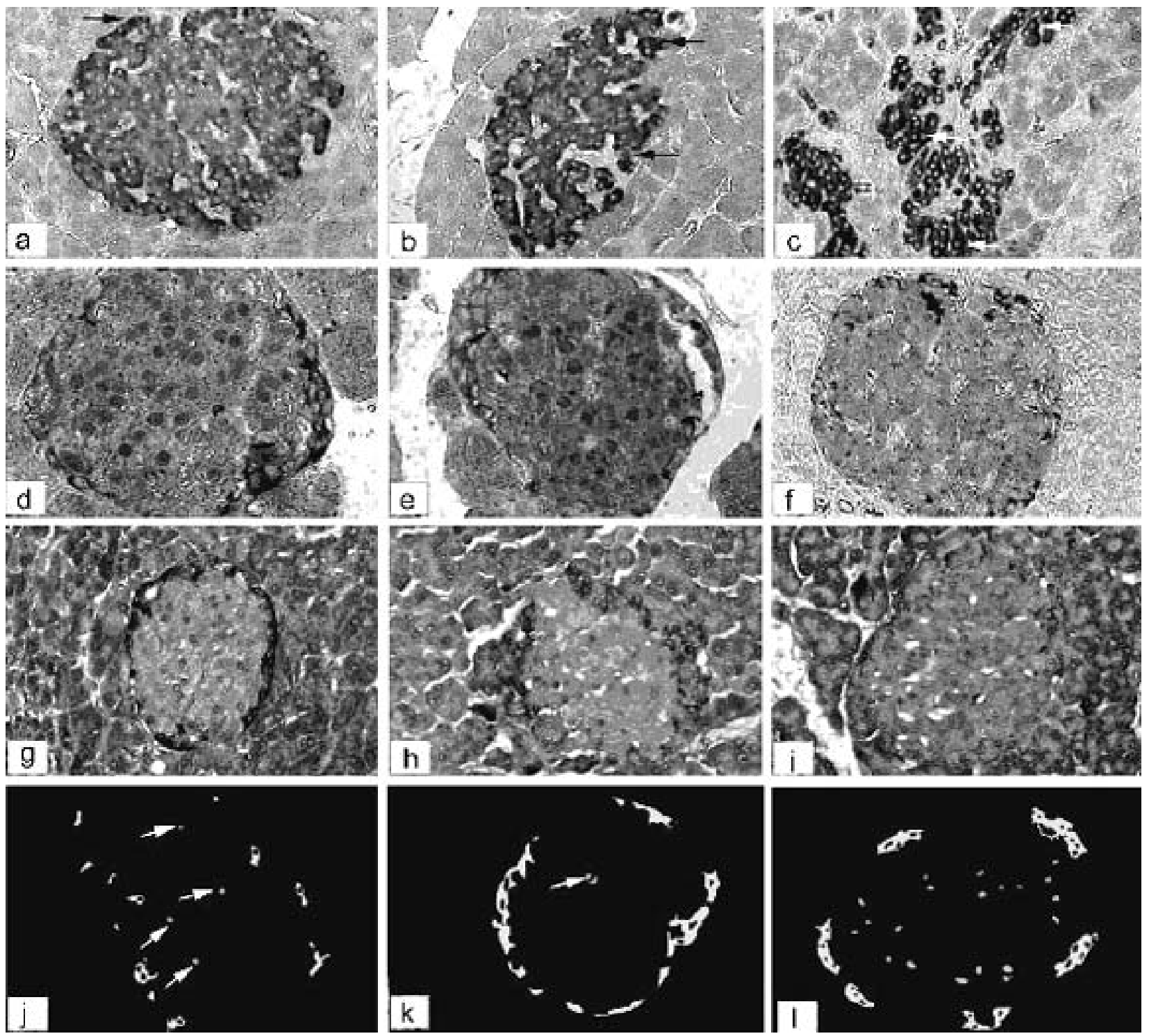

Figure 2 Pancreatic islets stained with different antibodies to show Vvi $\beta$ and replication rate, neogenesis and apoptosis. Double immunolabelling: nuclei are stained with proliferating cell nuclear antibody (PCNA) (arrows), while the cytoplasm shows insulin immunostaining (a, CD6; b, SRD6; c, SRD12; $\times 100) ; \beta$-cell nuclei are stained with PDX-1 (carbazole) and the periphery with INGAP (fast blue) (d, CD6; e, SRD6; f, SRD12; ×200); CK19-immunolabelled pancreatic islet; positive-reacting non- $\beta$-cells are seen in the periphery; counterstaining with haematoxylin ( $\mathrm{g}$, CD6; h, CD12; I, SRD12; ×100). Pancreatic cells with glucagon-positive cells in the periphery (immunofluorescence); apoptotic nuclei (propidium iodide) corresponding to $\beta$ cells are seen in the central zone of the islets (arrows) (j, CD6; k, SRD6; I, SRD12; ×100).

hamsters (Borelli et al. 2003), the decreased release of insulin observed in SRD12 rats could establish a vicious negative circle contributing to the lower capacity of rats to cope with the increased demand of insulin.

The limited time-capacity of the rat pancreas to cope with a prolonged period of sustained insulin resistance is an important issue when we consider the implementation of prevention strategies. We and other authors have previously shown that replacement of sucrose by starch
(Chicco et al.1999), administration of fish oil (Storlien et al. 1987, Lombardo et al. 1996, Soria et al. 2002) and troglitazone (Chicco et al. 2000) in the diet restored the altered pattern of serum lipids, insulin sensitivity, and glucose-induced insulin secretion in rats chronically fed a SRD. These results indicate that all these impaired functions are reversible and can be recovered when the animals receive the treatment in an appropriately timely manner. It remains to be demonstrated whether - and to 
Table 3 Changes induced by SRD feeding upon indicators of islet neogenesis

\begin{tabular}{|c|c|c|c|c|c|}
\hline & $\begin{array}{l}\text { Islet diameter } \\
(\mu \mathrm{m})\end{array}$ & $\begin{array}{l}\text { Cytokeratin islet index rate } \\
(\%)\end{array}$ & $\begin{array}{l}\text { Islet in contact with ducts } \\
(\%)\end{array}$ & $\begin{array}{l}\text { PDX-1 + islet cells } \\
(\%)\end{array}$ & $\begin{array}{l}\text { INGAP+ islet cells } \\
(\%)\end{array}$ \\
\hline \multicolumn{6}{|l|}{ Group } \\
\hline SRD6 & $173 \pm 12$ & $13 \cdot 9 \pm 2 \cdot 5$ & $43 \pm 6$ & $69 \cdot 3 \pm 12 \cdot 0$ & $0.14 \pm 0 \cdot 02$ \\
\hline CD12 & $161 \pm 8$ & $15 \cdot 0 \pm 4 \cdot 0$ & $42 \pm 4$ & $45 \cdot 7 \pm 2 \cdot 9 \bigcirc$ & $0 \cdot 20 \pm 0.03$ \\
\hline SRD12 & $169 \pm 4$ & $12 \cdot 8 \pm 5 \cdot 0$ & $41 \pm 5$ & $32 \cdot 4 \pm 3 \cdot 2$ & $0 \cdot 10 \pm 0 \cdot 01$ \\
\hline
\end{tabular}

Values represent the mean of four rat pancreases and three section levels \pm S.E.M.

- CD vs SRD (either at 6 or 12 months); ^CD6 vs CD12; $\bullet$ SRD6 vs SRD12. In all cases, P<0.02.

what extent - the same happens with the morphological SRD-induced islet cell alterations.

The pancreatic $\beta$-cell mass was also modified by the challenge of the increased demand of insulin induced by SRD administration (Lombardo et al. 1996, Del Zotto et al. 2002). We have currently reproduced the increase in $\beta$-cell Vvi observed in SRD6 rats reported by Lombardo et al. (1996). As occurred previously, this effect was due to an increase in the replication rate of these cells together with a marked decrease in their apoptotic rate (Del Zotto et al. 2002). In SRD12, however, the rate of PCNA was no longer increased and the apoptotic rate was significantly increased rather than decreased.

Apoptosis is a morphologically identifiable form of cell death triggered by a variety of metabolic stimuli, and it plays an important role in remodelling $\beta$-cell mass as the counterpart of proliferation (Wyllie et al. 1980, Steller 1995, Scaglia et al. 1997, Shafrir et al. 1999). Thus, it has been shown that $\beta$-cell expansion can be offset by concomitant apoptosis (Pick et al. 1998). Hoorens et al. (1996) postulated that rat $\beta$-cell apoptosis is blocked by proteins whose synthesis is stimulated by glucose in a dose-dependent manner, while Donath et al. (1999) and Federici et al. (2001) showed that glucose increases this rate by triggering an 'on and off' expression of specific genes. The decreased rate of $\beta$-cell apoptosis recorded in SRD6 and its increase in SRD12 could be ascribed to these two opposite mechanisms triggered by glucose. These results suggest that changes in apoptosis could explain the increased/decreased $\beta$-cell Vvi measured at the two periods, but these changes could not provide $\beta$-cells functionally sufficient to maintain normal levels of serum glucose and triacylglycerol.

We assessed the possible contribution of islet neogenesis to increasing $\beta$-cell Vvi by the use of several indicators such as the presence of cytokeratins (CKs) (Bowens et al. 1994, Wang et al. 1995) and the increase in replication rate, number of insulin-labelled cells at the ductal compartment (Bowens \& Klöppel 1996), proportion of small islets and of islets closely associated with the ductal epithelium (Bertelli et al. 2001), and percentage of PDX1-positive cells (Sharma et al. 1999, Perfetti et al. 2000, Stoffers et al. 2000). None of these indicators showed significant changes in SRD animals, thus suggesting that, in our rat experimental model, islet neogenesis was not involved in the mechanism responsible for the increment of $\beta$-cell Vvi.

Altogether, the reactive morphological changes, as well as insulin secretion, were time-limited and failed to overcome the sustained increased demand of insulin elicited by the chronic administration of SRD to normal rats.

We could observe substantial differences when we compared these data with those previously obtained in normal hamsters fed a SRD (Del Zotto et al. 1999, 2000, Massa et al. 2001). In these animals, both the shift in the dose-response curve (glucose stimulus) and the increase in $\beta$-cell Vvi and mass were sustained for up to 12 months. Another conspicuous difference was that hamsters showed an initial increase in islet neogenesis and in the number of INGAP-positive cells. In contrast to those observed in rats, the reactive changes detected in pancreas function and morphology in hamsters were sufficient to maintain fasting serum glucose and triacylglycerol levels within the normal range. We also found that the ratio $\beta$-cell mass/ body weight was three times larger in hamsters than in rats (Del Zotto et al. 2000). We therefore assumed that in order to maintain normal serum glucose and triacylglycerol levels for a long period after SRD administration, islet neogenesis must be present to ensure a sufficiently functional $\beta$-cell mass. Accordingly, SRD rats cannot maintain those parameters within a normal range due to their inability to reassume islet neogenesis in adult life.

It has been claimed that INGAP stimulates islet neogenesis (Rosenberg et al. 1983, Rafaeloff et al. 1997). In addition, we have previously shown an increase in the number of INGAP-positive cells accompanying the increased neogenesis rate induced by the chronic administration of SRD to normal hamsters (Del Zotto et al. 2000). Furthermore, in newborn hamsters fed a SRD during pregnancy, we identified the presence of islet and ductal cells with high replication rate co-expressing PDX-1 and INGAP (Gagliardino et al. 2003). In the rat, therefore, the absence of islet neogenesis signs, accompanied by either no changes (SRD6) or a decrease (SRD12) in the percentage of INGAP-positive cells, 
clearly contrasts with observations in the hamster, indicating a cause-effect relation rather than a simple coincidence. Although fully within the field of speculation, we might assume that the significant increase of INGAPpositive cells depicted in CD12 as compared with CD6 rats represents an effort of the rat pancreas to compensate for the low - or absent - neogenetic response to the INGAP stimulus (INGAP resistance?).

The moderate hyperglycaemia present in our rats and the altered glucose oxidation (decreased activity of the PDHc complex) recently reported in the same experimental model (Pighin et al. 2003) could represent an additional factor limiting the functional and morphological pancreas reaction. In fact, hyperglycaemia can impair the secretion of insulin (Leahy et al. 1986, Rossetti et al. 1987, Portha et al. 1988, Leahy 1996, Deng et al. 2004), the rate of $\beta$-cell replication and the degree of islet neogenesis (Maedler et al. 2001). Furthermore, it can also increase the rate of $\beta$-cell apoptosis (Donath et al. 1999, Federici et al. 2001, Maedler et al. 2001). The deleterious effect of glucose involves an impaired expression of genes related to glucose utilisation, $\beta$-cell replication and islet neogenesis (Weir et al. 2001, Laybutt et al. 2002). Hyperglycaemia, together with the increased triacylglycerol serum levels and the content of islet triglycerides (Pighin et al. 2003) gluco-lipotoxicity - could affect all these processes by increasing the rate of oxidative stress (Sakuraba et al. 2002, Robertson et al. 2004).

In brief, our current results and those previously reported by our group (Del Zotto et al. 1999, 2000, Gagliardino et al. 2003) show that the response of two animal models to a similar $\beta$-cell function overload is different, and that this response would be genetically determined. Thus, the efficacy of the mechanisms that attempt to control an increased demand of insulin induced by similar experimental procedures can vary, and these mechanisms may cause either a compensatory hyperinsulinaemic-normoglycaemic state or a diabetic state. In this context, the development of neogenesis would play a key role in obtaining a successful sustained adaptation to the increased demand of insulin. The concomitant absence of increase in the number of INGAPpositive cells and lack of a neogenetic reaction would support the idea of a stimulatory effect of this peptide upon neogenesis (Rosenberg et al. 1983, Rafaeloff et al. 1997, Del Zotto et al. 2000, Gagliardino et al. 2003). When neogenesis is absent, at least in our model, the other pancreatic reactive mechanisms cannot ensure such adaptation. At present, therefore, either removing or decreasing the insulin demand would be the most reasonable strategy to prevent diabetes manifestations in cases where neogenesis is not present. The fact that administration of fish oil to SRD rats improves pancreatic damage and metabolic homeostasis (Pighin et al. 2003) lends further support to this assumption. Further studies using models similar to the one currently used may help to determine the molecular mechanisms conditioning either the success or the failure of the pancreatic compensatory response to a functional overload.

\section{Acknowledgements}

This study was partially supported by funds from CONICET, CICPBA and FONCYT of Argentina. Thanks are due to C. Bianchi for helping with the immunohistochemistry, E. Gagliardino and Adrian Díaz for the insulin assay, and A. Di Maggio for careful secretarial support.

\section{References}

Bergmeyer HU 1974 Methods of Enzymatic Analysis, $2^{\text {nd }}$ edn, vols 1-4. New York: Academic Press.

Bertelli E, Regoli M, Orazioli D \& Bendayan M 2001 Association between islets of Langerhans and pancreatic ductal system in adult rat. Where endocrine and exocrine meet together? Diabetologia 44 575-584.

Bonner-Weir S 2000 Islet growth and development in the adult. Journal of Molecular Endocrinology 24 297-302.

Bonner-Weir S \& Smith FE 1994 Islet cell growth and the growth factors involved. Trends in Endocrinology and Metabolism 5 60-64.

Bonner-Weir S, Deery D, Leahy JL \& Weir GC 1989 Compensatory growth of pancreatic beta-cells in adult rats after short-term glucose infusion. Diabetes 38 49-53.

Borelli MI, Francini F \& Gagliardino JJ 2003 Autocrine regulation of glucose metabolism in pancreatic islets. American Journal of Physiological and Endocrinological Metabolism 286 E111-E115.

Bouwens L \& Klöppel G 1996 Islet cell neogenesis in the pancreas. Virchows Archiv 427 553-560.

Bouwens L, Wang RN, De Blay E, Pipeleers DG \& Klöppel G 1994 Cytokeratins as markers of ductal cell differentiation and islet neogenesis in the neonatal rat pancreas. Diabetes 43 1279-1283.

Chen NG \& Reaven GM 1999 Fatty acid inhibition of glucose-stimulated insulin secretion is enhanced in pancreatic islets from insulin-resistant rats. Metabolism 48 1314-1317.

Chicco A, Soria A, Fainstein-Day P, Gutman R \& Lombardo YB 1994 Multiphasic metabolic changes in the heart of rats fed a sucrose-rich diet. Hormone and Metabolic Research 26 397-403.

Chicco A, Bernal C, Soria A, Giangrossi G \& Lombardo YB 1999 Dietary effects of partial or total substitution of sucrose for starch on glucose and lipid metabolism in dyslipemic rats. Nutrition Research 19 281-293.

Chicco A, D'Alessandro ME, Karabatas L, Pastorale C, Basabe JC \& Lombardo YB 2003 Muscle lipid metabolism and insulin secretion are altered in insulin-resistant rats fed a high sucrose diet. Journal of Nutrition 133 127-133.

Clark A, Jones LC, de Koning E, Hansen BC \& Matthews DR 2001 Decreased insulin secretion in type 2 diabetes: a problem of cellular mass or function? Diabetes 50 (Suppl 1) S169-S171.

Cohen AM, Teitelbaum A \& Rosenman E 1977. Diabetes induced by a high fructose diet. Metabolism 26 17-24.

Del Zotto H, Massa L, Gómez Dumm CL \& Gagliardino JJ 1999 Changes induced by sucrose administration upon the morphology and function of pancreatic islets in the normal hamster. Diabetes-Metabolism Research and Reviews 15 106-112.

Del Zotto H, Massa L, Rafaeloff R, Pittenger GL, Vinik A, Gold G, Reifel-Miller A \& Gagliardino JJ 2000 Possible relationship between changes in islet neogenesis and islet neogenesis-associated protein-positive cell mass induced by sucrose administration to normal hamsters. Journal of Endocrinology 165 725-733. 
Del Zotto H, Gómez Dumm CL, Drago S, Fortino A, Luna GC \& Gagliardino JJ 2002 Mechanisms involved in the beta-cell mass increase induced by chronic sucrose feeding to normal rats. Journal of Endocrinology 174 225-231.

Deng S, Vatamaniuk M, Huang X, Doliba N, Lian MM, Frank A, Velidedeoglu E, Desai NM, Koeberlein B, Wolf B, Barker CF, Naji A, Matschinsky FM \& Markmann JF 2004 Structural and functional abnormalities in the islets isolated from type 2 diabetic subjects. Diabetes 53 624-632.

Donath MY, Gross DJ, Cerasi E \& Kaiser N 1999 Hyperglycemia-induced beta-cell apoptosis in pancreatic islets of Psammomys obesus during development of diabetes. Diabetes $\mathbf{4 8}$ 738-744.

Edlund H 1998 Transcribing pancreas. Diabetes 47 1817-1823.

Federici M, Hribal M, Perego L, Ranalli M, Caradonna Z, Perego C, Usellini L, Nano R, Bonini P, Bertuzzi F, Marlier LNJL, Davalli AM, Carandente O, Pontiroli AE, Melino G, Marchetti P, Lauro R, Sesti G \& Folli F 2001 High glucose causes apoptosis in cultured human pancreatic islets of Langerhans: a potential role for regulation of specific $\mathrm{Bcl}$ family genes toward an apoptotic cell death program. Diabetes 50 1290-1301.

Flores LE, García ME, Borelli MI, Del Zotto H, Alzugaray ME, Maiztegui B \& Gagliardino JJ 2003 Expression of islet neogenesis-associated protein in islet of normal hamsters. Journal of Endocrinology 177 243-248.

Gagliardino JJ, Del Zotto H, Massa L, Flores LE \& Borelli MI 2003 Pancreatic duodenal homeobox-1 and islet neogenesis-associated protein: a possible combined marker of activateable pancreatic cell precursors. Journal of Endocrinology 177 249-259.

Gradwohl G, Dierich A, LeMeur M \& Guillemot F 2000 Neurogenin 3 is required for the development of the four endocrine cell lineages of the pancreas. PNAS 97 1607-1611.

Herbert V, Lau KS, Gottlieb CW \& Bleicher SJ 1965 Coated charcoal immunoassay of insulin. Journal of Clinical Endocrinology and Metabolism 25 1375-1384.

Hoorens A, Van de Casteele M, Kloppel G \& Pipeleers D 1996 Glucose promotes survival of rat pancreatic beta cells by activating synthesis of proteins which suppress a constitutive apoptotic program. Journal of Clinical Investigation 98 1568-1574.

Hsu SM, Raine L \& Fanger H 1981 Use of avidin-biotin-peroxidase complex $(\mathrm{ABC})$ in immunoperoxidase techniques: a comparison between $\mathrm{ABC}$ and unlabeled antibody (PAP) procedures. Journal of Histochemistry and Cytochemistry 29 577-580.

Jensen J, Heller RS, Funder-Nielsen T, Pedersen EE, Lindsell C, Weinmaster G, Madsen OD \& Serup P 2000 Independent development of pancreatic alpha- and beta-cells from neurogenin3-expressing precursors: a role for the notch pathway in repression of premature differentiation. Diabetes 49 163-176.

Jonas JC, Sharma A, Hasenkamp W, Ilkova H, Patane G, Laybutt R, Bonner-Weir S \& Weir GC 1999 Chronic hyperglycemia triggers loss of pancreatic beta cell differentiation in an animal model of diabetes. Journal of Biological Chemistry 274 14112-14121.

Lacy PE \& Kostianovsky M 1967 Method for the isolation of intact islet of Langerhans from the rat pancreas. Diabetes 16 35-39.

Laurell S 1966 A method for routine determination of plasma triglycerides. Scandinavian Journal of Clinical and Laboratory Investigation 18 668-672.

Laybutt DR, Weir GC, Kaneto H, Lebet J, Palmiter RD, Sharma A \& Bonner-Weir S 2002 Overexpression of c-Myc in beta-cells of transgenic mice causes proliferation and apoptosis, downregulation of insulin gene expression, and diabetes. Diabetes 51 1793-1804.

Leahy JL 1996 Impaired B-cell function with chronic hyperglycemia: 'overworked B-cell' hypothesis. Diabetes Reviews 4 298-319.

Leahy JL, Cooper HE, Deal DA \& Weir GC 1986 Chronic hyperglycemia is associated with impaired glucose influence on insulin secretion: a study in normal rats using chronic in vivo glucose infusion. Journal of Clinical Investigation 77 908-915.
Leibiger IB, Leibiger B \& Berggren PO 2002 Insulin feedback action on pancreatic beta-cell function. FEBS Letters 532 1-6.

Linde S, Hansen B \& Lernmark A 1980 Stable iodinated polypeptide hormones prepared by polyacrylamide gel electrophoresis. Annals of Biochemistry 107 165-176.

Lombardo YB, Drago S, Chicco A, Fainstein-Day P, Gutman R, Gagliardino JJ \& Gómez Dumm CL 1996 Long-term administration of a sucrose-rich diet to normal rats: relationship between metabolic and hormonal profiles and morphological changes in the endocrine pancreas. Metabolism 45 1527-1532.

Madsen OD, Jensen J, Petersen HV, Pedersen EE, Oster A, Andersen FG, Jorgensen MC, Jensen PB, Larsson LI \& Serup P 1997 Transcription factors contributing to the pancreatic beta-cell phenotype. Hormone and Metabolic Research 29 265-270.

Maedler K, Spinas GA, Lehmann R, Sergeev P, Weber M, Fontana A, Kaiser N \& Donath MY 2001 Glucose induces beta-cell apoptosis via upregulation of the Fas receptor in human islets. Diabetes 50 1683-1690.

Massa L, Del Zotto H, Gómez Dumm CL \& Gagliardino JJ 1997 Postnatal sequential changes in islet morphology and insulin secretion of normal hamsters. Pancreas 14 58-64.

Massa ML, Borelli MI, Del Zotto H \& Gagliardino JJ 2001 Changes induced by sucrose administration on glucose metabolism in pancreatic islets in normal hamsters. Journal of Endocrinology 171 551-556.

McKinnon CM \& Docherty K 2001 Pancreatic duodenal homeobox-1, PDX-1, a major regulator of beta cell identity and function. Diabetologia 44 1203-1214.

Milburn JL Jr, Hirose H, Lee YH, Nagasawa Y, Ogawa A, Ohneda M, Beltrandel Río H, Newgard CB, Johnson JH \& Unger RH 1995 Pancreatic beta-cells in obesity. Evidence for induction of functional, morphologic, and metabolic abnormalities by increased long chain fatty acids. Journal of Biological Chemistry 270 1295-1299.

Montanya E, Nacher V, Biarnés M \& Soler J 2000 Linear correlation between beta-cell mass and body weight throughout the lifespan in Lewis rats: role of beta-cell hyperplasia and hypertrophy. Diabetes 49 1341-1346.

Parsons JA, Brelje TC \& Sorenson RL 1992 Adaptation of islets of Langerhans to pregnancy: increased islet cell proliferation and insulin secretion correlates with the onset of placental lactogen secretion. Endocrinology 130 1459-1466.

Perfetti R, Zhou J, Doyle ME \& Egan JM 2000 Glucagon-like peptide- 1 induces cell proliferation and pancreatic-duodenum homeobox-1 expression and increases endocrine cell mass in the pancreas of old, glucose-intolerant rats. Endocrinology 141 4600-4605.

Pick A, Clark J, Kubstrup C, Levisetti M, Pugh W, Bonner-Weir S \& Polonsky KS 1998 Role of apoptosis in failure of beta-cell mass compensation for insulin resistance and beta-cell defects in the male Zucker diabetic fatty rat. Diabetes 47 358-364.

Pighin D, Karabatas L, Rossi A, Chicco A, Basabe JC \& Lombardo YB 2003 Fish oil affects pancreatic fat storage, pyruvate dehydrogenase complex activity and insulin secretion in rats fed a sucrose-rich diet. Journal of Nutrition 133 4095-4101.

Polonsky KS, Sturis J \& Bell GI 1996 Seminars in Medicine of the Beth Israel Hospital, Boston. Non-insulin-dependent diabetes mellitus - a genetically programmed failure of the beta cell to compensate for insulin resistance. New England Journal of Medicine $334777-783$.

Portha B, Giroix MH, Serradas P, Welsh N, Hellerstrom C, Sener A \& Malaisse WJ 1988 Insulin production and glucose metabolism in isolated pancreatic islets of rats with NIDDM. Diabetes $\mathbf{3 7}$ 1226-1233.

Rafaeloff R, Pittenger GL, Barlow SW, Qin XF, Yan B, Rosenberg L, Duguid WP \& Vinik AI 1997 Cloning and sequencing of the pancreatic islet neogenesis associated protein (INGAP) gene and its expression in islet neogenesis in hamsters. Journal of Clinical Investigation 99 2100-2109. 
Robertson RP, Harmon J, Tran PO \& Poitout V 2004 Beta-cell glucose toxicity, lipotoxicity, and chronic oxidative stress in type 2 diabetes. Diabetes 53 (Suppl 1) S119-S124.

Rosenberg L, Brown RA \& Duguid WP 1983 A new approach to the induction of duct epithelial hyperplasia and nesidioblastosis by cellophane wrapping of the hamster pancreas. Journal of Surgical Research 35 63-72.

Rossetti L, Shulman GI, Zawalich W \& DeFronzo RA 1987 Effect of chronic hyperglycemia on in vivo insulin secretion in partially pancreatectomized rats. Journal of Clinical Investigation 80 1037-1044.

Sakuraba H, Mizukami H, Yagihashi N, Wada R, Hanyu C \& Yagihashi S 2002 Reduced beta-cell mass and expresion of oxidative stress-related DNA damage in the islet of Japanese type II diabetic patients. Diabetologia 45 85-96.

Scaglia L, Cahill CJ, Finegood DT \& Bonner-Weir S 1997 Apoptosis participates in the remodelling of the endocrine pancreas in the neonatal rat. Endocrinology 138 1736-1741.

Shafrir E, Ben-Sasson R \& Bar-On H 1999 Insulin resistance, B-cell survival, and apoptosis in type 2 diabetes: animal models and human implications. Diabetes Reviews 7 114-123.

Sharma A, Zangen DH, Reitz P, Taneja M, Lissauer ME, Miller CP, Weir GC, Habener JF \& Bonner-Weir S 1999 The homeodomain protein IDX-1 increases after an early burst of proliferation during pancreatic regeneration. Diabetes 48 507-513.

Soria A, Chicco A, Eugenia D'Alessandro M, Rossi A \& Lombardo YB 2002 Dietary fish oil reverse epididymal tissue adiposity, cell hypertrophy and insulin resistance in dyslipemic sucrose fed rat model. Journal of Nutritional Biochemistry 13 209-218.
Steller H 1995 Mechanisms and genes of cellular suicide. Science 267 1445-1449.

Stoffers DA, Kieffer TJ, Hussain MA, Drucker DJ, Bonner-Weir S, Habener JF \& Egan JM 2000 Insulinotropic glucagon-like peptide 1 agonists stimulate expression of homeodomain protein IDX-1 and increase islet size in mouse pancreas. Diabetes 49 741-748.

Storlien LH, Kraegen EW, Chisholm DJ, Ford GL, Bruce DG \& Pascoe WS 1987 Fish oil prevents insulin resistance induced by high-fat feeding in rats. Science 237 885-888.

Wang RN, Klöppel G \& Bouwens L 1995 Duct-to-islet-cell differentiation and islet growth in the pancreas of duct-ligated adult rats. Diabetologia 38 1405-1411.

Weir GC, Laybutt DR, Kaneto H, Bonner-Weir S \& Sharma A 2001 Beta-cell adaptation and decompensation during the progression of diabetes. Diabetes 50 (Suppl 1) S154-S159.

Wyllie AH, Kerr JF \& Currie AR 1980 Cell death: the significance of apoptosis. International Review of Cytology 68 251-306.

Zhou YP \& Grill V 1995 Long term exposure to fatty acids and ketones inhibits B-cell functions in human pancreatic islets of Langerhans. Journal of Clinical Endocrinology and Metabolism 80 $1584-1590$.

Received 28 May 2004

Accepted 21 July 2004

Made available online as an Accepted Preprint

5 August 2004 